Article

\title{
Bypassing Government: Aid Effectiveness and Malawi's Local Development Fund
}

\author{
Michael Chasukwa ${ }^{1, *}$ and Dan Banik ${ }^{2}$ \\ ${ }^{1}$ Department of Political and Administrative Studies, University of Malawi, Zomba, Malawi; E-Mail: mchasukwa@cc.ac.mw \\ ${ }^{2}$ Centre for Development and the Environment, University of Oslo, 0317 Oslo, Norway; E-Mail: dan.banik@sum.uio.no \\ * Corresponding author
}

Submitted: 3 December 2018 | Accepted: 27 March 2019 | Published: 5 June 2019

\begin{abstract}
Many practical and action-oriented international roadmaps to improve the quality of aid and its delivery and impact on development-including the Paris Declaration, Accra Agenda for Action, and Busan Partnership-emphasize a more active involvement of domestic institutions and procedures. Despite widespread agreement among both donor and recipient countries on this issue, we find that aid often tends to bypass national institutional structures. This practice is sometimes justified on grounds of high levels of political and administrative corruption and weak implementation capacity in recipient country bureaucracies. We examine how and to what extent multilateral and bilateral development agencies bypass national and local government institutions while channeling aid and the impact of such practices on aid effectiveness in Africa. Based on an empirical study of project aid and budget support provided to Malawi by the World Bank, the African Development Bank, and the German Economic Group, we argue that earmarked funding, specialized procurement arrangements, and the proliferation of Project Management Units are among the mechanisms used to circumvent the involvement of national institutions. We conclude that while such practices may achieve short-term gains by displaying successful and visible 'donorship', the long-term impact is more uncertain. The bypassing of local institutions results in fragmentation of aid, lack of coordination among aid industry actors, and a general weakening of policy space and domestic capacity to formulate and implement development policy.
\end{abstract}

\section{Keywords}

Africa; aid; development; institutions; Malawi; policy

Issue

This article is part of the issue "Aid Impact and Effectiveness", edited by Rachel M. Gisselquist and Finn Tarp (UNU-WIDER, Finland).

(C) 2019 by UNU-WIDER; licensee Cogitatio (Lisbon, Portugal). This article is licensed under a Creative Commons Attribution 4.0 International License (CC BY).

\section{Introduction}

Ever since the end of WWII, and the provision of capital by the United States to Europe, there has been considerable academic and policy interest in whether and to what extent foreign aid promotes economic development. Even among the most ardent supporters of foreign aid there is a recurring desire to ensure that disbursed funds are used efficiently and effectively to meet project and program goals. Thus, we have witnessed in recent years a growing interest among aid agencies and con- sultants to monitor and evaluate what is often termed 'aid effectiveness.' And several international roadmaps to improve the quality of aid and its delivery and impact on development-including the Paris Declaration (OECD, 2005), Accra Agenda for Action (AAA; OECD, 2008), and Busan Partnership (OECD, 2011)-emphasize a more active involvement of domestic institutions and procedures. Despite widespread agreement among both donor and recipient countries on the issue of 'ownership,' we argue that a large amount of disbursed aid continues to bypass national institutional structures. Such 
practices are often justified by donors as necessary due to high levels of political and administrative corruption and weak implementation capacity in recipient country bureaucracies.

While all actors in the aid industry demand that aid should be effective, they disagree on how it should be delivered to ensure effectiveness. In this article, we examine how and to what extent multilateral and bilateral development agencies bypass national and local government institutions while channeling aid and the impact of such practices on aid effectiveness in Africa. Our empirical focus is Malawi, heavily aid-dependent and recently ranked the third poorest country in the world. We study project aid and budget support provided to the country's Local Development Fund (LDF) by the World Bank, the African Development Bank (AfDB), and the German Economic Group (KfW). Designed as an inter-governmental fiscal transfer mechanism, the LDF was established by the Government of Malawi in 2009 to mobilize resources for poverty reduction interventions in accordance with the provisions of international agreements that promoted greater harmonization of aid and recipient government ownership. The initiative functioned as a basket fund, pooling resources for development and governance projects at the local level, with the Government of Malawi given the power to spend resources at its own discretion but based on the national policies such as the Malawi Growth and Development Strategy. The government envisioned that the LDF, as a pooled fund, would enable better coordination of the numerous projects that donors were implementing at the local level either on their own or through civil society organizations. The goal was to stop donors bypassing the country's public administration and ensure greater effectiveness of disbursed development aid to local councils by actively making use of government structures.

We examine the functioning of the LDF in practice and the extent to which it has promoted harmonized policies and aid aligned to the needs and goals of the national government. In particular, we critically analyze how earmarked funding, specialized procurement arrangements, and the creation of a specialized Project Management Unit (PMU) have been used by donors to bypass the involvement, and curtail the power, of national institutions. Our study is based in fieldwork conducted in Malawi in the period 2015-2018. In addition to visiting LDF projects in four districts-Lilongwe, Zomba, Thyolo, and Mangochi-we conducted forty-five in-depth interviews with local and national government officials as well as those representing the three donor agencies-the World Bank, AfDB and KfW German Economic Bank. The research districts were purposively sampled based on their performance and rating regarding LDF projects. The in-depth interviews were semistructured to allow detailed probing of themes being examined. At the local council level, respondents were selected from the directorates of Planning and Development, Public Works, and Finance-agencies that are sig- nificantly involved in LDF projects and hence conversant with issues that were being examined. We also interviewed traditional authorities (chiefs), local councilors, and Members of Parliament (MPs). In-depth interviews were conducted with officials from the Ministry of Local Government and Rural Development, the Ministry of Finance, the National Local Government Finance Committee, and the LDF-Technical Support Team (hereafter LDF-TST). The informants were identified on the basis of being key players in the aid industry either as donors or policymakers in Malawi. They represented a variety of public institutions and aid agencies, thus allowing us to achieve triangulation and solicit diverse views. With the agreement of our informants, all interviews have been anonymized given the sensitive nature of the topic.

In Section 2, we briefly examine the relationship between aid and development, with a particular focus on the evolution and growing popularity of the international aid effectiveness agenda in recent decades. In Section 3, we undertake a discussion of aid dependency in Malawi, setting the scene for our empirical focus. Following this, we introduce the LDF in Section 4 before analyzing its functioning and impact in relation to four sets of issues: earmarked funding and procurement procedures; coordination and project management; aid and patronage politics; and institutional design and competition for scarce resources. We end with some concluding reflections on the effectiveness of bypass strategies.

\section{Foreign Aid for Development}

The historical foundations of foreign aid are numerous. In addition to political ideology, foreign policy, commercial interests, and national security, there are large elements of altruism and a desire to reduce global poverty. The world of foreign aid is complex and includes Official Development Assistance (concessional flows with a grant element of at least $25 \%$ ) and development, humanitarian, and emergency aid provided by non-governmental organizations, civil society organizations, bilateral donors, and multilateral agencies.

Over the past couple of decades, there have been interesting exchanges on the conceptual foundations and effectiveness of providing aid. Some, like Calderisi (2006, p. 163), argue that 'foreign aid, as a whole, has not worked,' particularly in Africa. Such conclusions strengthen the arguments of scholars like Easterly (2006), who has famously made the case for 'searchers,' i.e. those who not only find things that work but also accept responsibility for their actions, in contrast to 'planners,' who are supposedly more interested in applying 'global blueprints' than in adapting to local conditions. Jeffrey Sachs has responded by claiming that by not making careful distinctions across countries and types of programs, such conclusions suffer from a major methodological error and end up conveying 'a misplaced sense of helplessness in the face of massive but solvable problems' (Sachs, 2006, p. 1309). 
The arguments in favor of aid typically emphasize the positive and significant impact that it has on growtheven though the magnitude of such an effect may be low (Clemens, Radelet, \& Bhavnani, 2004). Some argue that aid finances crucial public investments required for infrastructure and physical and human capital, and improves fiscal discipline (e.g. tax collection and reform). Sustained donor-recipient dialogue with flexible conditionality also increases aid effectiveness (Dalgaard, Hansen, \& Tarp, 2004; Hansen \& Tarp, 2001). The empirical literature, however, does not offer a clear theoretical model on how aid affects economic growth (Easterly, 2003). Indeed, many influential quantitative studies do not find an independent effect of foreign aid on economic growth (Burnside \& Dollar, 2000; Collier \& Dollar, 2002). Thus, those who argue the case against aid typically point to the large number of African countries that have experienced little economic growth despite being major recipients of aid for decades. They highlight several explanations for this lack of success: large areas with poor infrastructure networks and over-dependence on primary commodity exports; poor governance and weak political commitment to market reform; and inadequate resources for financial investment. With such factors in mind, some conclude that it is not possible to test the 'absolute effectiveness' of aid but rather only the 'marginal effectiveness' (Morrissey, 2006).

Other voices, some from Africa (e.g. Moyo, 2009), claim that trade, and not aid, is crucial for economic growth. Although aid is often conditioned on recipient countries respecting democratic rights, donors themselves often do not abide by such values. The argument is that aid often results in a large and ineffective public sector and is an impediment for private sector development. Without fiscal and budgetary discipline, large public bureaucracies, funded with aid money, breed corruption (Ayittey, 2005). Moreover, some studies show that aid to a repressive regime helps consolidate its power through corruption and exploitation (Bueno de Mesquita, Smith, Siverson, \& Morrow, 2003), while others argue that aid should only be given to countries already implementing good policies (Dollar \& Levin, 2004).

\subsection{The Aid Effectiveness Agenda}

Since the Monterrey International Conference on Financing for Development (in 2002), there been an increased focus on the type and quality of foreign aid that can most effectively reduce poverty. The movement for aid effectiveness received a further boost with the Paris Declaration (2005), which recommended local ownership of policies by recipient countries; alignment of development programs in accordance with developing country priorities; harmonization of practices among donors in order to avoid fragmentation, duplication, and high transaction costs; creation of a results framework for measuring impact; and increased mutual accountability and transparency of aid flows. The commitments made in Paris were followed by the signing in 2008 of the AAA, which reiterated the importance of strengthening three key aspects of aid: ownership, inclusive partnerships, and delivery of results (OECD, 2008). The AAA also served as a forum for reviewing progress in meeting targets achieved since the Paris Declaration. The direction and volume of aid flows are historically contingent, and some studies have highlighted how voting patterns in the UN, colonial ties, and political and strategic considerations continue to shape global aid flows (Alesina \& Dollar, 2000; Bermeo, 2018; Dietrich, 2013, 2018; Easterly, 2006; Knack, 2004). The growing role of emerging donors including India, China and Brazil was also discussed at AAA, and all actors-donors and recipientswere encouraged to abide by the Paris principles in promoting coordinated and effective aid. The Paris and Accra meetings, however, did not result in major changes in the nature, type and predictability of aid flows and some (e.g. Woods, 2008) argued that aid remained dysfunctional, fragmented and duplicative. China, in particular, has become very assertive in foreign aid policies, and through the Forum on China-Africa Cooperation, the Chinese government has increased its support for the activities of Chinese state-owned enterprises and private sector actors in Africa. It thus interacts in numerous ways with poorer countries, including through so-called 'South-South' dialogues, which give access to natural resources and new and growing markets, and reduce the dependence of African countries on traditional forms of aid. Rather than providing budget support to governments, and conditioning aid on support for democracy and gender equality, the Chinese model emphasizes the principles of 'winwin,' 'mutual respect,' 'friendship,' and 'non-interference' (Banik, 2013; Banik \& Chasukwa, 2016).

Key debates on aid effectiveness have centred on selectivity and modalities. The major proponents of aid selectivity for increased effectiveness argue that aid should be given to countries that have good policies because they will deliver on what aid ought to achieve (Burnside \& Dollar, 1997, 2004). Thus, Burnside and Dollar (2004) claim that good policies will not only make aid more effective, but that they will also succeed in facilitating economic growth. In practice, donors use such arguments when providing tied aid aimed at improving the policy environment of recipient countries. However, aid selectivity remains controversial. For example, Dietrich, 2013, p. 208) notes how donors continue to give aid to countries with not so good policies:

In 2008, Haiti, a developing country with an abysmal record of governance, received more than 700 million US dollars in bilateral development assistance from OECD donor countries, amounting to roughly 70 dollars of aid per capita. In the same year, Tanzania, whose institutions of intermediate strength bode well for effective aid implementation, received around 2 billion US dollars in bilateral assistance, equivalent to approximately 47 dollars in per capita aid. 
Despite the controversy surrounding aid selectivity, donors continue to implement reforms aimed at reducing fragmentation of aid and improving the policy environment in recipient countries. Oh and $\operatorname{Kim}(2015$, p. 92) argue that aid proliferation occurs when donor budgets increase, which in turn gives rise to fragmented aid. Thus, the proliferation of aid can harm economic growth in recipient countries. Moreover, such proliferation is an obstacle to effective aid as interventions are uncoordinated and primarily tend to address the interests of donors and not those of recipient countries. When donors split their aid, the result is often an increase in mechanisms by which they can choose to bypass local government structures citing institutional and human capacity inadequacies and corruption (Dietrich \& Winters, 2016; Quibria, 2014). A typical bypass involves 'donors channeling aid through intergovernmental or nongovernmental organizations (IGOs and NGOs) and providing in-kind aid like food and medicine directly to citizens in recipient countries' (Dietrich, 2013, p. 208). In this age of competitive bilateralism and multilateralism, donors also engage the private sector in circumventing local government structures. In a typical bypass, donors are in control of the aid, and retain control over most decisions on how aid is allocated and spent. Such bypass mechanisms give donors the discretion to make decisions that have direct or indirect impact on government policies.

The fast-changing international aid landscape and the growing role of civil society and private organizations as well as emerging countries as providers of aid was the focus of the Busan Partnership for Effective Development Cooperation (OECD, 2011). A major outcome was agreement on a two-tier approach (voluntary for emerging donors) that committed signatories to continued commitment to development and greater accountability of their own actions and inactions (Burnell, 1997; Leiderer, 2013; Oya, 2006; Dreher et al., 2014). The modalities for achieving such results, however, remain unclear. Some studies have identified structural bottlenecks in the implementation of the Paris principles, including the absence of donor accountability and credible penalties for non-compliance (Rogerson, 2005) and the dominance of a 'planning' mind-set that downplays the role of actors with diverse and competing interests (Barder, 2009). Others have argued that the principles of 'harmonization' and 'ownership' are incompatible (Hyden, 2008).

Wolfensohn (1999, p. 9) describes partnership in development aid as a relationship 'led by governments and parliaments of the countries, influenced by the civil society of those countries, and joined by the domestic and international private sectors, and by bilateral and multilateral donors.' A common feature of the declarations in Paris, Accra, and Busan is the importance of treating donors and recipients as equals. These declarations thus re-vitalized previous international discussions that emphasized partnership, including the 1969 Pearson Commission report on development partners and the 1980 Brandt Commission report, 'North-South: A Program for
Survival' (Maxwell \& Riddell, as cited in Crawford, 2003, p. 140). Since the Paris Declaration, the aid community has attached growing importance to budget support, particularly in Africa. For example, $20 \%$ of donor flows in Mozambique in the year the Paris Declaration was signed was budget support (Renzio \& Hanlon, 2009, p. 258), while in Tanzania around $40 \%$ of aid in 2009 was channeled through the national budget as compared to $30 \%$ in 2002 (Harrison, Mulley, \& Holtom, 2009, p. 281). Budget support comes in different forms and includes so-called 'pooled development funds' - which are 'arrangements where donors provide financial contributions towards a common set of broad objectives and where allocations for specific activities are decided by a joint governing mechanism' (Ball \& Beijnum, 2010, p. 3). Others highlight that pooled funds are 'a financing arrangement where donors pool their resources using a special account...managed by one of the participating donors or by the respective line ministries' (Bandstein, 2007, p. 3). Thus, a key issue appears to be close collaboration, with the recipient country taking the lead in determining the policies that are to be supported and deciding the policy instruments and interventions to be used in pursuing policy objectives. In other words, donors agree to contribute resources to pooled funds to support the policies that have been determined by the national governments of aid-receiving countries. By supporting such national policies and priorities, donor agencies aim to fulfil their pledge to promote harmonization, mutual accountability, results management, and respect for country-owned policies and structures, as espoused in the 2005 Paris Declaration.

While donors, development agencies and aidrecipient countries may agree on enhancing overall effectiveness of development aid, operationalizing such agreements in practice has always been a challenge. Parties to aid agreements and policies have frequently renegaded on their promises and responsibilities in pursuit of individual goals. Thus, despite promises made in Paris, Accra and Busan on the importance of strengthening global partnerships for increased harmonization of aid, bypass mechanisms-as exemplified by the proliferation of PMUs-have continued to flourish (Abdel-Malek, 2015; Li, 2017). The reluctance to phase out PMUs is perhaps also a reflection of the new donor landscape, with the entrance of emerging countries and philanthropic organizations. And current assessments of the quality of aid pays little or no attention to the existence of PMUs. The emphasis on 'value for money' and 'quantification of results/outputs' by most major donors has contributed to the increased usage of bypass arrangements and reversion to project modality in aid delivery as donors show increased interest in balancing score sheets and ticking the right boxes (Yanguas, 2018). Indeed, Bermeo (2018) argue that although 'targeted development' is meant to reach out to specific vulnerable groups, the continued use of project aid and PMUs show that such efforts fall into the same trap that of the 'results agenda'. The aid industry appears to have been reduced to chasing 
matrices, since mobilization of resources by donors and development agencies is dependent on the available proof to have successfully completed 'value for money' interventions that can document high impact on beneficiaries. With both donors and recipients under pressure to identify and report projects that can document 'value for money', the current global partnership framework has the potential of compromising aid effectiveness.

\section{Malawi: Development in a Highly Aid-Dependent Context}

With growing climate-related threats to agricultural production, millions of Malawians regularly go to bed hungry every night. Moreover, the country does not perform well in international rankings such as those on human development and perceptions of corruption. For example, with a Human Development Index value of 0.477 in 2017 (below the average of 0.504 for countries in the Low Human Development group and below the average of 0.537 for countries in Sub-Saharan Africa), Malawi is ranked 171 out of 189 countries in a newly released UNDP statistical update. Indeed, many Western analysts have even begun to propagate the idea that Malawi is unique-'There are developing countries, and then there is Malawi'-implying that a sense of hopelessness characterizes the country's development trajectory (Banik, 2018). All of this points to a paradox: despite peace, political stability, and consistent support for democracy, a large majority of the country's rapidly growing population (estimated to be over 18 million) has not witnessed radical improvement in their living standards (Banik, 2018).

Malawi is particularly interesting as it is heavily dependent on bilateral and multilateral donors to meet the cost of implementing its national budget. This has made the country highly vulnerable to external influence on matters of economic development. Indeed, the proxy influence of donors on development policies can be gauged from the extent of budgetary support they provide. A focus on Malawi to study the aid effectiveness agenda is also interesting as the country has implemented several bold policies-on occasion against the wishes of influential foreign aid donors-that have worked for short periods in promoting food security, but have subsequently been overshadowed by political patronage, corruption, and leakages.

According to Van der Meer, Tostensen, Slob and Jerve (2008, p. 17), foreign aid as a proportion of the government budget averaged 38\% over the period 1994-2006, the bulk of which was grants (averaging $72 \%$ of all foreign aid). The situation today is not much different, with donor funds accounting for $38 \%$ of the total budget in the 2013-14 fiscal year (Van der Meer et al., 2008). Between 2004 and 2010, Malawi consistently received less in loans than in grants. For instance, DAC statistics indicate that the country received $7 \%$ of total Official Devel- opment Assistance (ODA) as loans and $93 \%$ as grants in 2010 (Amundsen, 2017). The trend of grants dominating the aid flows continued between 2012 and 2015 with $83 \%$ of assistance provided as grants in 2012-13, 77\% in 2013-14, and $80 \%$ in the 2014-15 (Malawi Government, 2015b). Although grants have continues to dominate, loans have increased slightly over the years, with the World Bank providing the majority of loans. The percentage of assistance provided as loans increased from $14 \%$ in $2012-13$ to $19 \%$ in $2013-14$, and then decreased slightly (still a net increase from 2012-13 to 2014-15) to $17 \%$ in 2014-15. In 2014-15, the World Bank provided $61 \%$ of all assistance delivered through loans. Among bilateral donors, the United States of America and the United Kingdom are the largest funding partners (Malawi Government, 2015b).

Malawi's external debt stock was US\$1,783 million as of December 2015, with multilaterals accounting for US\$1,323 million, while the debt portfolios for bilateral and commercial creditors were US\$428.8 million and US\$114.5 million, respectively. The International Development Association of the World Bank, the International Monetary Fund, and the AfDB are the major multilateral creditors, accounting for $47 \%, 20 \%$, and $18 \%$, respectively.

Since 2013, the World Bank has been the largest source of financing to Malawi, providing about $45 \%$ of all loan disbursements (Malawi Government, 2015a). It is anticipated that the organization will continue to play a major role, as its current Country Assistance Strategy shows that US\$300 million has been committed to Malawi for a five-year period (Malawi Government, 2015a). The AfDB has been the second largest source of foreign loans, with $13 \%$ of all loan disbursements made since 2013 (Malawi Government, 2017). According to the AfDB's Country Strategy Paper, the planned disbursements amount to US\$820 million over a five-year period, of which US\$266 million is on non-concessional terms.

China and India are the major bilateral creditors, with $54 \%$ and $35 \%$ of debts, respectively. China is a relatively new development partner, which has been offering semi/non-concessional loans since 2008. Currently, China represents $15 \%$ of disbursements on all loans made since 2012. India, which is another relatively new development partner, has accounted for $15 \%$ of all loan disbursements received by the Government of Malawi since 2012. Other non-Paris bilateral lenders, including Kuwait Fund, Saudi Fund and the United Arab Emirates, are expected to provide US\$205 million over five years starting in 2016. Poland, a new non-traditional donor, has indicated willingness to support Malawi's development agenda on a non-concessional basis (Malawi Government, 2017).

In theory, all development aid, including bilateral and multilateral assistance, is governed by the Malawi Development Cooperation Strategy launched in $2014 .{ }^{1}$ In practice, however, external actors hold the upper hand. The

\footnotetext{
${ }_{1}^{1}$ The current Malawi Development Cooperation Strategy succeeds the previous Development Assistance Strategy (2006-2011).
} 
relationship between successive Malawian governments and donors has been largely cordial, although there have been several disagreements and confrontations. All five regimes $^{2}$ that have governed the country since 1994 have experienced either withdrawal or suspension of aid. For example, aid was withdrawn during the reign of Hastings Kamuzu Banda on account of bad governance and violation of human rights (Meinhardt \& Patel, 2003; Resnick, 2012). Similar reasons were cited when aid was withdrawn during subsequent administrations (Von Hagen \& Schulz, 2009; Wroe, 2012). Budget support has been suspended on numerous occasions, including 2002, 2003, 2011, and 2012-13 (Amundsen, 2017). The punitive actions on the aid front have often resulted in successive Malawian governments accusing donors of neocolonization and meddling in domestic politics with the aim of initiating regime change. Following a major corruption scandal in 2013-dubbed 'Cashgate' - major donors including the United Kingdom, Norway, and the European Union suspended their budget support, although they continued to deliver aid through projects, programs, and pooled funds. This decision by donors, which continues today, has raised questions on the preferred aid modalities of traditional aid-givers and the future scenarios under which aid will be provided to Malawi.

\section{The Local Development Fund}

Aid is channeled to developing countries through either on-budget or off-budget categories. On-budget aid modalities are generally preferred by recipient countries as they, not donors, control the resources and decide how these should be allocated. In many situations, donors prefer to deliver aid through off-budget modalities, where they retain greater control of the agenda and can more directly try to design and implement interventions in recipient countries that are key to their interests.

Motivated by the need to promote increased harmonization of aid and closer alignment with national development priorities ${ }^{3}$ following major international declarations and agreements in Paris, Accra, and Busan, the Malawian government established the LDF in 2009 as an inter-governmental fiscal transfer mechanism aimed at mobilizing finance for poverty reduction. The LDFwhich evolved from the Malawi Social Action Fund (MASAF) and was established in 1995 with seed funds from the World Bank and the Government of Malawiis designed to function as a discretionary public financing grant facility that can quickly disburse funds for development projects to local governments. The LDF was established as a basket fund where the government and all donors could pool their resources for development and governance projects at the local level. The pooled funds were aimed at improving aid governance by en- suring that there were only a few players in the local development sector, who could easily coordinate and work with each other. The government was given the mandate to spend LDF funds at its discretion, as long as these decisions were based on national policies and priorities.

The LDF pools and disburses funds through four funding windows-community, urban, local authority, and performance. Donors (or 'development partners') mainly contribute with financial aid and technical support. The combined contributions of the World Bank, KfW, and AfDB for the period 2009-2014 was approx. US\$126 million, which constituted $62 \%$ of the total funds received by the LDF in this period. The World Bank, with US\$107.8 million, was the major financier, followed by the AfDB (USD 17 million) and KfW (US\$1.8 million) (LDF-TST, 2015a). In accordance with the agreement signed with donors, the Government of Malawi provided the remaining funds in cash and kind (e.g. providing office space and paying salaries of selected staff). The government's cash contribution was highly unstable, and payments were often less than the agreed amounts. During fieldwork, the significant role of donors in funding the LDF was acknowledged by a government official, who remarked, 'LDF is much about donors when it comes to making the finances available to roll out the activities.'4 The key point is that LDF is heavily donor dependent. This heavy reliance on donors has weakened the ability of the government to improve aid coordination. As of June 2014, the LDF funding portfolio was at US\$245 million, including commitments by donors and the government of Malawi for projects until 2019 (LDF-TST, 2015a, p. 3).

\subsection{Earmarked Funding and Procurement Procedures}

The LDF itself entails an administrative bypass, as funds are centrally managed by the LDF-TST instead of the National Local Government Finance Committee-the constitutional body mandated to manage all development funds that target local councils. Staff at LDF-TST sign contracts with the Ministry of Finance giving the impression that they are part of the civil service and using government salary scale. However, LDF-TST employees have different conditions of service from those of civil servants and their salaries are above those of Malawian civil servants. Since its operational costs are covered by the World Bank, the LDF-TST is often referred to as a 'super-NGO that implements activities of donors other than those of the central government and local councils. ${ }^{5}$ Contrary to the rules of the LDF pooled funding, donors earmark their resources. For example, the funding windows are attached to specific donors, which has allowed these actors to profile themselves as promoting specific developmental agendas. Thus, the World Bank funds three windows (local authority, perfor-

\footnotetext{
2 Hastings Kamuzu Banda (July 1964-May 1994), Bakili Muluzi (May 1994-May 2004), Bingu wa Mutharika (May 2004-April 2012), Joyce Banda (April 2012-May 2014), and Peter wa Mutharika (2014-present).

3 These include the Malawi Growth and Development Strategy (MGDS II), the Decentralization Policy and the Local Government Act.

${ }^{4}$ Key informant interview, Ministry of Finance, Lilongwe, 4 December 2015.

${ }^{5}$ Key informant interview, Ministry of Local Government and Rural Development, Lilongwe, 8 December 2015.
} 
mance, and community), which are used to implement public works programs and community demand-driven projects, mainly related to the construction of school blocks and teachers' houses.

A senior official of the LDF-TST observed:

When we receive funding from the World Bank, we actually know what it is supposed to be spent on. Any expenditure outside the identified project is queried. The next thing are threats on suspension and withdraw of funding as well as penalties.' ${ }^{6}$

It is important to note that these are the very same activities that the Bank previously funded (1995-2007) during the final three stages of the MASAF. The KfW and AfDB fund and identify closely with the urban window. And KfW funds are earmarked for two activities: 'construction of socio-economic infrastructure (bus stations, stadia, markets, administrative buildings) and urban planning' (LDF-TST, 2015b, p. 15). Just as the World Bank's record of funding activities reflects its previous LDF priorities, the $\mathrm{KfW}$ had previously funded and prioritized construction activities (through the Secondary Centers Development Program) for over two decades in the period 1985-2007. In the LDF, KfW activities are aimed at boosting the local revenue base of urban councils. For this purpose, it has provided earmarked funds for the construction of markets, bus stations, and halls (LDF-TST, 2015a). Even in the LDF where councils 'identify' their projects and the KfW provide funds, the projects are similar to those that the KfW funded under Secondary Centers Development Program (LDF-TST, 2015b). And just like the World Bank and $\mathrm{KfW}$, the AfDB continues to fund LDF activities in local economic development that are very similar to the Poverty Alleviation Program it funded in 1994.

Given such trends, a local government official claimed that the:

LDF has been an earmarked fund from the start. The 'pooling' of funds is to the convenience of donors because they want to be seen to be using government structures although that is only on paper and not in practice. Government does not determine which projects are to be implemented. ${ }^{7}$

Such earmarked funding in the LDF was justified by donors as a necessary strategy to ensure that aid is allocated to strategic interventions. As an official of the AfDB noted:

We do our assessments that tell us which projects and activities to fund. Above all, we also do have our own areas of interest indicated in our Country Development Assistance Plan that we have to stick to. Earmarking is in the best interest of donors and stakeholders we serve-government and community members. ${ }^{8}$

While the government provides, in principle, matching funds to all LDF windows, donors have continued to fund their pet projects but give the impression of aligning their interests with the financing arrangements and priorities of the government. Indeed, the impression given is that previously prioritized funding mechanisms are now 'surrendered' to the LDF for the sake of improved effectiveness and in the name of good 'donorship.' One of the implications of this arrangement is that each funding agency (donor) requires the LDF-TST to follow their own specific procedures which means the Malawi Procurement Act is not applied when procuring goods and services with funds from donors. An example is the advert on a technical audit for beneficiary verification of the World Bank-funded social cash transfer program in Malawi. In the advert, it was highlighted that 'the selection Procedures shall be in accordance with the World Bank Procedures' (LDF-TST, 2018, p. 2). Similarly, the shortlisting and selection of audit services for the AfDB-funded projects were based on the the selection procedure...in accordance with the AfDB's Procurement Policy Framework' (LDF-TST, 2015b, p. 2). Such diversity in procurement procedures creates numerous challenges-including increased costs, delays in decision-making, an overwhelmed and overburdened administrative staff, and delays in project completionwhich in turn impact the effectiveness of aid.

Managing aid is not easy and there are numerous challenges on the ground. A respondent from the LDF-TST noted: 'We work under pressure and get confused. We have several forms to complete and reports for individual donors to write. We are told they need to have their impact isolated from other donors. ${ }^{9}$ Indeed, the dominant narrative was that the LDF-TST and local council officials spend a considerable amount of their time on paperwork.

\subsection{Coordination and Project Management}

Realizing that the country in 2009 had over 48 PMUs that involved 12 donors and functioned parallel to national institutions and policies, the government banned the creation of new PMUs (Nilsson \& Nkhoma, 2014). Many of the existing PMUs were in the health sector. Despite the presence of a relatively well-organized SectorWide Approach (SWAp), around 100 projects from more than 20 donors provided funding to the health sector outside of the SWAp arrangement (OECD, 2012). ${ }^{10}$ The

\footnotetext{
${ }^{6}$ Key informant interview, LDF-TST, Lilongwe, 7 January 2016.

${ }^{7}$ Key informant interview, local government official, Directorate of Planning and Development, Mangochi, 19 January 2016.

${ }^{8}$ Key informant interview, AfDB, Lilongwe, 22 March 2016.

${ }^{9}$ Key informant interview, LDF-TST, Lilongwe, 25 March 2016.

10 SWAp refers to mechanisms 'by which Governments and donors can support the development of a sector in an integrated fashion through a single sector policy and expenditure programme, under Government leadership, using common management and reporting procedures and progressing towards the use of Government procedures to disburse and account for all funds' (Foster \& Fozzard, 2000, p. 55).
} 
government indicated that its intention was to phase out 27 PMUs by 2011 (OECD, 2012). However, by 2015, Malawi still had 33 PMUs-six more than the 27 parallel PMUs that the Government was aiming to have by 2011. Moreover, parallel PMUs were still being established upon the insistence of donors, who made the establishment of parallel PMUs a condition for providing aid. Thus, of the 33 parallel PMUs that existed in 2015, six were affiliated to donors participating in the LDF-World Bank (5) and AfDB (1).

In our interactions with the World Bank and KfW, we were often told that the LDF is a pooled fund managed by the Government of Malawi. However, government officials claimed that the LDF is managed by a parallel PMUtermed the LDF-TST. As an official in the Ministry of Local Government put it:

The LDF-TST operates outside government machinery...[O]n paper they appear to be part of government but in practice they are not-they do their own project planning, handle finances and hold discussions with donors on their own. ${ }^{11}$

Indeed, having investigated the organizational set-up of the LDF, we find considerable evidence that the LDFTST is a parallel bypass rather than an embedded PMU. For an entity to qualify as an embedded PMU, it must meet three of the following four criteria: (a) the terms of reference for externally appointed staff are determined by the country implementation agency, not by the donor; (b) the most senior staff member is to be appointed by the country implementation agency, not by the donor; (c) the salary structure of national staff (including benefits) must not be higher than that of civil service personnel; and (d) the entity must be accountable to the country's implementing agencies, and not to external funding agencies (Ministry of Finance, cited in Said, McGrath, Grant, \& Chapman, 2011, pp. 27-28). We find that the LDF does not meet three of the criteria above. In fact, the LDF only meets one criterion-the most professional staff member is to be appointed by the country implementation agency, and not by the donor. Even this criterion has to be qualified because donors have a say in the recruitment of professionals as they vet all applications. A senior AfDB official, however, disagreed with this view: 'We have always believed that the LDF-TST is government institution because employees have their job contracts with government. ${ }^{12}$

What then is the problem with PMUs such as those in the LDF? Many argue that PMUs are actively used to bypass government structures by virtue of the enormous amount of funds committed to project support (under donor control) as opposed to general budget support and sector support, which constitute pooled funds under the control of the government. For example, in
2011, 67\% of all foreign aid resources in Malawi were allocated to project support and a mere $10 \%$ to budget support and 23\% to sector support (Malawi Government, 2015b). Thus, a large chunk of aid is disbursed through channels that are not preferred by the government. The major concern is that such active bypass of public institutions neither contributes to capacity building of weak institutions nor improves the already fragile legitimacy of political and administrative structures. The circumvention denies public institutions the opportunity to acquire experience by working with the best practices and policies that donors would like them to follow in order to deliver effective aid. The result appears to be 'amplification effects' (Ndulo, 2014) in that institutions that were weak remain weak while those that were strong become stronger. For example, the LDF has fortified institutions like the LDF-TST that are outside the public machinery as donors have equipped such entities with the best and latest technology, in addition to adequate funding for attracting and retaining well-qualified staff, who in turn have been effective in lobbying influential actors both in the donor community and in government. A respondent from the Ministry of Local Government indicated, 'We see a trend of variation regarding councils responding to interventions. Performing councils are improving their operations. The struggling councils are still struggling. ${ }^{13}$

The assertion by Booth (2011) that capacity will not be built in developing countries if donors continue to avoid working with existing institutions, is applicable in the context of the LDF. Instead of avoiding institutions, weak as they may be, the 'thinking and working politically' (TWP) literature on the integration of politics in development theory and practice (Dasandi, Marquette, \& Robinson, 2016) calls for donors to work with local institutions in order to understand the factors blocking effective delivery of aid and to jointly devise solutions to problems. TWP emphasizes the point made by critics of bypass structures that aid modalities will have to change from 'best practice' to 'best fit' to align with donors' interests and programs of the recipient country. TWP also insists that both donors and aid recipients are active political players in the aid industry and as such the 'best fit' modalities need to be informed by the politics of institutional design between the givers and recipients of aid.

\subsection{Aid and Patronage Politics}

One of the main reasons donors bypass the government machinery is to avoid political and administrative mismanagement and resulting delays, as well as misallocation of aid. The LDF is a major financing mechanism for local development and decentralization projects at the local council level in Malawi. The power enjoyed by the PMU (LDF-TST) rests mainly on its ability to prevent aid being used for unintended purposes. The country's po-

\footnotetext{
$\overline{11}$ Key informant interview, Rural Development Officer, the Ministry of Local Government, Lilongwe, 19 April 2016.

12 Key informant interview, Senior Technical Officer, AfDB, Lilongwe, 12 April 2016.

13 Key informant interview, Ministry of Local Government and Rural Development, Lilongwe, 27 March 2016.
} 
litical elites have historically shown considerable interest in using aid for personal economic gain as well as political survival. Given the massive funds that go into the LDF, successive ruling parties have tried to ensure that their chosen candidates are appointed to the most senior positions. This helps to make policies and strategies more palatable to the government, especially in relation to the distribution of LDF resources. Political appointees ensure that their political patrons can continue to access resources that would otherwise be difficult to gain control over. These officials tend to support projects championed by political parties. As an LDF official noted, 'those appointed based on political colors are willing to help the political party to get resources with or without technical justification.' ${ }^{14}$ An example was the executive director of the LDF (2009-2010) who ensured that two successive ministers of local government were able to establish so-called Rural Growth Centers in their home districts despite those not originally meeting the selection criteria. ${ }^{15}$ An official in the Ministry of Local Government claimed that the incumbent minister had 'influenced allocation of funds to a stadium under the urban window to his constituency when it did not qualify using the set criteria.' 16

Another way for politicians to promote their personal interests is to encourage temporary ('acting') appointments at the LDF. Such interim officers offer less resistance than permanent staff and are more likely to redirect resources according to the preferences of influential political leaders. The local communities also highlighted the role of Members of Parliament in diverting resources for projects that were not earmarked: 'The MP interferes a lot with our work in the Village Development Committee. When the MPs fails to get a project at the district council, he/she approaches us with directives' ${ }^{\prime 17}$ Thus, we find considerable evidence of political pressure on the LDF-TST to allocate projects in the constituencies of political elites, including serving Cabinet ministers. And a popular view among officials in the ministries of local government and finance was that each minister was able to influence projects in their respective constituencies that would not have been possible if proper procedures were followed.

The LDF experience demonstrates that even when there is an attempt to ring-fence and protect aid, recipient country politicians continue to find ways of accessing and influencing the distribution of such resources. Both public officials and donors routinely break resource allocation procedures when faced with pressure from elected representatives in order not to be seen as sabotaging a country's political agenda and demonstrating loyalty to the wishes of the electorate. In diverting aid to personal projects and rewarding individuals and groups for political support and loyalty, both formal and informal rules of the game are applied. Informal procedures are particularly popular when the interests of donors differ from those of elected representatives, MPs and council members. The case of diverting Rural Growth Centers to districts that are politically important is an example. The Malawian government borrowed US\$14 million and US\$3.04 million from the AfDB and the World Bank, respectively, to fund the construction of these centers (AfDB, 2008). When the criteria to allocate such centers to particular districts were manipulated by political leaders, the AfDB did not raise any concern, possibly for fear of jeopardizing the credit agreement with the Malawian Government relating to the loan.

The Malawian case is not unique in this regard. Using regional data on aid projects financed by the World Bank and the AfDB, Ohler and Nunnenkamp (2014) analyze the motives governing these two multilateral donors' aid allocation in 27 African countries. They do not find any evidence supporting the donors' claim that more aid was given to the neediest regions, defined on the basis of infant mortality, maternal health, and undernutrition. Rather, regions in which political leaders were born were likely to receive more multilateral aid, in particular for physical infrastructure projects, which reinforces the belief that political favoritism plays an important role in aid allocations (Nunnenkamp, Ohler, \& Andres, 2017). Thus, aid deepens patronage politics as political elites find ways of using aid for their political purposes.

Donors can hence play Ostrich politics in that they may deliberately ignore local malpractices, turning a blind eye to the messy realities of development projects as long as their own interests are served (Reltien, 2001). Our review of the LDF experience in Malawi suggests that there is a possibility of donors becoming clients. This is particularly the case when a donor or a group of donors face competition from others for the attention of recipient country policymakers. The growing influence of new development actors such as China is putting pressure on more established actors to compromise their standards in order to stay relevant. Such an understanding departs from the mainstream literature, particularly on public sector reforms, which indicates that it is only recipient countries that practice clientelism and patronage. While Hyden (2008) suggests that donors are complicit in promoting patronage in aid-receiving countries, we argue that donors can be patrons or clients-or what Yanguas (2014) calls 'spoilers'-depending on the context. Development agencies are under pressure to perform to the satisfaction of their constituents and the head office. The head office is in turn interested in seeing the

\footnotetext{
14 Interview, LDF-TST official, Lilongwe, 13 April 2016.

15 LDF-TST has had four Executive Directors since its inception: Sam Kakhobwe, Edward Sawerengera, Ted Kalebe, and Charles Mandala.

16 Interview, Ministry of Local Government official, Lilongwe, 9 April 2016. In the same interview, the respondent narrated how another minister appointed by the People's Party administration influenced the construction of a community secondary school and a market in her constituency. The projects remained unfinished as the contractor and the Ministry of Local Government are currently fighting a court case related to corruption as part of the Cashgate scandal.

17 Interview with member of the Village Development Committee chairperson, Thyolo, 7 March 2017.
} 
impact and attaining value for money for the resources pumped into a particular country. The processes and procedures required to achieve positive impact and value for money may be of less concern to the head office, hence the temptation for the country staff of aid agencies to act as clients (abiding by the wishes of local politicians) as they focus on delivering what is expected of them by the head office. The emerging consensus in the context of the 'messy politics' of development aid (Yanguas, 2018 ) is that aid has small but positive effect on economic growth (Arndt, Jones, \& Tarp, 2011). The diverging views on about aid effectiveness originate from difficulties in measuring the effectiveness of aid (Bourguignon \& Sundberg, 2007).

\subsection{Institutional Design and Competition for Scarce Resources}

The LDF is designed as a collective financing mechanism for local development realized through the harmonization of donor-funded projects under the stewardship of the Malawian Government. All district councils should thus ideally interact with the government rather than with individual donors. In 2008, the government also made a commitment to harmonize its institutional procedures relating to local development financing and established a single institution - the National Local Government Finance Committee-with the mandate to interact with local councils and other players on matters of local development (GOPA, 2005). However, in practice we find that this mandate is shared with the LDF. And the current institutional design allows local councils and others to interact directly with the LDF-TST, contrary to the original design. This is a major problem because while the Ministry of the Local Government and Rural Development and the National Local Government Finance Committee are bypassed in decision-making, these are in reality the institutions with the official mandate to guide local councils. Thus, the donors use the LDF-TST to interact with local councils and implement their projects rather than engaging with the national government.

Since the LDF offers four financing windows, there is now increased competition in the local development sector to access multiple opportunities for funding. The windows that are heavily competed for are those funded by donors - the community, local authority, and urban windows. Because of its perceived pressure to fund local council activities as well as serve donor and government interests, the LDF has extended its mandate to become a grants provider. Thus, the LDF now plays a double role-as a grants-issuing institution as well as a PMU. For example, it awards projects to local councils in the urban window. And for all such projects funded by the $\mathrm{KfW}$, allocation is based on an expression of interest through a donor-influenced application process which differs from the constitutionally approved intergovernmental fiscal formula. Thus, in the KfW urban window-funded projects, local councils submit their applications and compete among themselves for the grants. The essence of awarding projects on a competitive basis is that councils have to prove that they have both the technical and financial capacity to complete projects within an agreed timeframe. While such competition in awarding projects may promote innovative solutions (e.g. construction of stadia and bus depots for local revenue generation), implementation is often problematic as councils tend to undercut practices among themselves in a bid to win the projects (e.g. district versus town councils). By becoming a grants-issuing unit, the LDF is searching for ways to survive the government-led restructuring process and yet doing a disservice to the aid effectiveness agenda.

The competition to attract the resources that come with aid is also intense among elected representatives at both central government and local council levels. Such competition among councilors and MPs occurs view of other local development financing mechanisms under the control of the central government (e.g. the Constituency Development Fund and the District Development Fund). The increase of earmarked funds for a specific group (such as the Constituency Development Fund for MPs) leads to increased competition among different stakeholders. A local council official made a critical observation: 'We implement many projects that are outside the development plans hence sometimes not really responding to the immediate needs of our local communities. ${ }^{18}$ The implication is that councils often experience allocative inefficiency as resources are invested in wrong sectors/areas.

Scholars have previously argued that MPs and councils in Malawi routinely tussle over financial resources to develop their local constituencies (Cammack, Kanyongolo, Gooloba-Mutebi, \& O’Neil, 2007; Chinsinga, 2005; Tambulasi, 2009). This competition for resources has a negative impact on aid effectiveness as both administrators and elected officials aim to use the resources for career development and for gaining political mileage, which do not necessarily address the needs of local individuals and households.

\section{Conclusion}

While the international aid discourse routinely highlights the importance of harmonized policies and aid disbursements aligned to the needs and goals of recipient governments, there are numerous disagreements on how this can best be implemented on the ground. The aim of our study was to examine how and to what extent multilateral and bilateral development agencies bypass national and local government institutions while channeling aid, and the impact of such practices on aid effectiveness in Africa. A focus on Malawi, which is heavily dependent on bilateral and multilateral aid, is particularly illustrative of the challenges many countries face in achieving devel-

\footnotetext{
18 Key informant interview, Thyolo District Council, Thyolo, 18 March 2017.
} 
opment outcomes when their policy space is limited by the dominant role and influence of external actors in national policymaking and implementation.

Donors often choose to bypass national institutions while implementing development projects citing inadequate administrative capacity, unhealthy political interference, and widespread corruption. In turn, political leaders in aid-dependent countries often choose not to challenge donor practices and reforms that are aimed at bypassing national institutions in order to improve aid effectiveness. Rather, they may choose to focus their energy on devising ways to redirect such resources to themselves and their preferred constituents.

The LDF was established to address the growing problem of uncoordinated aid targeting local development. In order to check the uncontrolled proliferation of aid agencies and projects, a basket fund was created that would pool resources and strengthen the ability of the government to better devise and implement development and governance projects at the local level in line with its national policy priorities. In practice, however, the LDF has ended up largely bypassing administrative structures, which in turn has created frustration among officials and slowed down the aid effectiveness agenda in Malawi. Earmarked funding, specialized procurement arrangements, and the establishment of specialized PMUs are among the mechanisms used by donors to circumvent the involvement of national institutions. Thus, we find that aid sometimes weakens the very institutions it aims to build and strengthen (Booth, 2011).

The growing use of bypass mechanisms to circumvent the public administration in aid-receiving countries is often justified on the grounds of weak public financial management system, low local capacity to absorb aid, low capacity to formulate and implement programs, high risk of using aid for unintended purposes (patronage and clientelism), and mixed priorities on the part of both donors and aid recipients. But donors also have their own reasons that compel them to create bypassesvisibility/publicity of their efforts, documenting attribution and impact of their projects, and pursuing specific goals such as policy influence. However, rather than promoting the principles of greater local ownership, capacity building, and harmonization of available external resources, we find that bypass mechanisms are fragmenting aid delivery and negatively affecting its effectiveness.

Our findings support the call by Eichenauer and Reinsberg (2017) for a re-examination of the hypothesis that bypasses are always the fastest way of delivering aid to local communities. Indeed, not all bypasses will be successful in delivering quick and efficient aid to local communities. Rather, the effectiveness of bypass strategies will depend on the type of institutional design adopted and the existing rules of the game that incentivize actors to make quick decisions and implement such policies effectively in line with original intentions. The reality on the ground is that recipient country governments continue to prefer budget support, as this gives them more control of resources and allows them to make decisions regarding expenditure and allocation. In contrast, many donors are showing a growing preference for project and program aid, which they can more easily control. The aid architecture in Sub-Saharan Africa has, in recent decades, witnessed a pendulum swing from project/program aid to budget support and then back to project aid.

The Malawian case demonstrates that aid effectiveness is compromised by the reluctance of both donors and recipients to more aggressively confront problems that arise from the practice of patronage politics. We conclude that while bypass practices may achieve short-term gains by displaying successful and visible 'donorship,' the long-term impact is more uncertain. The overall conclusion is that the bypassing of local institutions results in fragmentation of aid, lack of coordination among aid industry actors, and a general weakening of policy space and domestic capacity to formulate and implement development policy.

\section{Acknowledgments}

We would like to acknowledge financial and administrative support given by NORAD through the NORHED Programme for the project, 'Strengthening capacity for democratic and economic governance in Malawi.' The project is jointly implemented by the Centre for Development and the Environment at the University of Oslo and the Department of Political and Administrative Studies at the University of Malawi. The views expressed in this article do not necessarily represent the views of the funders.

\section{Conflict of Interests}

The authors declare no conflict of interests.

\section{References}

Abdel-Malek, T. (2015). The global partnership for effective development cooperation: Origins, actions and future prospects. Bonn: German Development Institute.

African Development Bank. (2008). Project appraisal report. Abidjan: African Development Bank.

Alesina, A., \& Dollar, D. (2000). Who gives aid to whom and why? Journal of Economic Growth, 5(1), 33-63.

Amundsen, I. (2017). Malawi: Country evaluation brief. Oslo: Norwegian Agency for Development Cooperation.

Arndt, C., Jones, S. \& Tarp, F. (2011). Aid effectiveness: Opening the black box (WIDER Working Paper No. 2011/044). Helsinki: UNU-WIDER.

Ayittey, G. B. N. (Ed.). (2005). Africa unchained: The blueprint for Africa's future. New York, NY: Palgrave.

Ball, N., \& Beijnum, M. (2010). Pooled funding for transition at the country level. Geneva: United National Development Program. 
Bandstein, S. (2007). What determines the choice of aid modalities? A framework for assessing incentive structures. Karlstad: Swedish Agency for Development Evaluation.

Banik, D. (2013). China and poverty reduction in Africa. In G. Yu (Ed.), Rethinking law and development: The Chinese experience (pp. 215-246). London: Routledge.

Banik, D. (2018). The Malawi paradox. The Oslo SDG Blog. Retrieved from https://www.sum.uio.no/english/ sdg/blog/dan-banik/the-malawi-paradox.html

Banik, D., \& Chasukwa, M. (2016). The impact of emerging donors on development and poverty reduction. In D. Banik \& B. Chinsinga (Eds.), The democratic dividend: Political transition and inclusive development in Malawi (pp. 147-168). London: Routledge.

Barder, O. M. (2009). Beyond planning: Markets and networks for better aid (Working Paper, No. 185). Washington, DC, and London: Center for Global Development.

Bermeo, S. (2018). Targeted development: Industrialised country strategy in a globalizing world. Oxford: Oxford University Press.

Booth, D. (2011). Working with the grain and swimming against the tide: Barriers to uptake of research findings on governance and public services in lowincome Africa (African Power Politics Program, Working Paper, No. 18). London: Overseas Development Institute.

Bourguignon, F., \& Sundberg, M. (2007). Aid effectiveness: The opening of the black box. The American Economic Review, 97(2), 316-321.

Bueno de Mesquita, B., Smith, A., Siverson, R. M., \& Morrow, J. D. (2003). The logic of political survival. Boston, MA: MIT Press.

Burnell, P. (1997). Foreign aid in a changing world. Buckingham: Open University Press.

Burnside, C., \& Dollar, D. (1997). Aid, policies, and growth (World Bank Policy Research Working Paper No. 569252). Washington, DC: World Bank.

Burnside, C., \& Dollar, D. (2000). Aid, policies and growth. American Economic Review, 90(4), 847-868.

Burnside, C., \& Dollar, D. (2004). Aid, policies and growth: Revisiting evidence (Policy Research Working Paper No. 3251). Washington, DC: World Bank.

Calderisi, R. (2006). The trouble with Africa: Why foreign aid is not working. New Haven, CT: Yale University Press.

Cammack, D., Kanyongolo, F., Gooloba-Mutebi, F., \& O'Neil, T. (2007). Neopatrimonial politics, decentralization and local government: Uganda and Malawi in 2006 (Overseas Development Institute, Working Paper, No. 2). London: Overseas Development Institute.

Chinsinga, B. (2005). District assemblies in a fix: The perils of the politics of capacity in the political and administrative reforms in Malawi. Development Southern Africa, 22(4), 529-548.

Clemens, M., Radelet, S., \& Bhavnani, R. (2004). The short-term effect of aid on growth (Working Paper No.
44). Washington, DC, and London: Centre for Global Development.

Collier, P., \& Dollar, D. (2002). Aid allocation and poverty reduction. European Economic Review, 46(8), 1475-1500.

Crawford, G. (2003). Democratization in Ghana: Assessing the impact of political aid (1997-2003). Paper presented at ECPR Conference, Marburg, Germany.

Dalgaard, C. J., Hansen, H., \& Tarp, F. (2004). On the empirics of foreign aid and growth. Economic Journal, 114(496), F191-F216.

Dasandi, N., Marquette, H., \& Robinson, M. (2016). Thinking and working politically: From theory building to building an evidence base (Development Leadership Programme, Research Paper No. 37). Birmingham: University of Birmingham.

Dietrich, S. (2013) Bypass or engage? Explaining donor delivery tactics in foreign aid allocation. International Studies Quarterly, 57(4), 698-712.

Dietrich, S., \& Winters, M. (2016). Foreign aid and government legitimacy. Journal of Experimental Political Science, 2(2), 164-171.

Dollar, D., \& Levin, V. (2004). The increasing selectivity of foreign aid, 1984-2002 (Working Paper No. 3299). Washington, DC: World Bank.

Dreher, A., Fuchs, A., Hodler, R., Parks, B. C., Raschky, P. A., \& Tierney, M. J. (2014). Aid on demand: African leaders and the geography of China's foreign assistance (AidData Working Paper No. 3). Virginia: AidData.

Easterly, W. (2003). Can foreign aid buy growth? Journal of Economic Perspectives, 17(3), 23-48.

Easterly, W. (2006). The white man's burden: Why the West's efforts to aid the rest have done so much ill and so little good. New York, NY: Penguin.

Eichenauer, V. Z., \& Reinsberg, B. (2017). What determines earmarked funding to international development organizations? Evidence from the new multi-bi aid data. The Review of International Organizations, 12(2), 171-197.

Foster, M., \& Fozzard, A. (2000). Aid and public expenditure (Working Paper No. 141). London: Overseas Development Institute.

GOPA. (2005). Functional review of Local Development Fund/MASAF. Lilongwe, Malawi: KfW.

Hansen, H., \& Tarp, F. (2001). Aid and growth regressions. Journal of Development Economics, 64(2), 547-570.

Harrison, G., Mulley, S., \& Holtom, D. (2009). Tanzania: A genuine case of recipient leadership in the aid system? In L. Whitfield (Ed.), The politics of aid: African strategies for dealing with donors (pp. 271-298). Oxford: Oxford University Press.

Hyden, G. (2008). After the Paris declaration: Taking on the issue of power. Development Policy Review, 26(3), 259-274.

Knack, S. (2004). Aid dependence and the quality of governance: Cross-country empirical tests. Southern Economic Journal, 64(2), 310-329. 
LDF-TST. (2015a). The local development fund: Establishment, successes and challenges-An outlook on the local development funding mechanism 2009 to 2014. Lilongwe: Local Development Fund.

LDF-TST. (2015b). Expression of interest: Provision of procurement audit for local economic development project. Lilongwe: Local Development Fund.

LDF-TST. (2018). Technical audit for social cash transfer and beneficiary verification. The World Bank. Retrieved from http://projects.worldbank.org/ procurement/noticeoverview?lang=en\&id= OP00048289

Leiderer, S. (2013). Donor coordination for effective government policies? Aid, Social Policy and Development, 27(8), 1422-1445.

Li, X. (2017). Should China join the GPEDC? The prospects for China and the global partnership for effective development co-operation (Discussion Paper, No. 17/2017). Bonn: German Development Institute.

Malawi Government. (2015a). Malawi aid atlas. Lilongwe, Malawi: Ministry of Finance.

Malawi Government. (2015b). Malawi development cooperation atlas: 2012/13, 2013/14, 2014/15. Lilongwe: Ministry of Finance, Economic Planning and Development.

Malawi Government. (2017). 2016 public debt management report. Lilongwe: Ministry of Finance, Economic Planning and Development.

Meinhardt, H., \& Patel, N. (2003). Malawi's process of democratic transition: An analysis of political developments between 1990 and 2003. Lilongwe: Konrad Adenauer Foundation.

Morrissey, O. (2006). Aid or trade, or aid and trade? The Australian Economic Review, 39(1), 78-88.

Moyo, D. (2009). Dead aid: Why aid is not working and how there is a better way for Africa. New York, NY: Farrar, Straus and Giroux.

Ndulo, M. (2014). Introduction. In M., Ndulo \& N., Walle (Eds.), Problems, promises and paradoxes of aid (pp. 1-15). Newcastle: Cambridge Scholars Publishers.

Nilsson, K., \& Nkhoma, B. B. (2014). Short-term learning for long-term impact: Lessons on project design from Malawi. In R. J. Shaw, N. V. Anh, \& T. H. Dang (Eds.), Sustainable water and sanitation services for all in a fast-changing world: Proceedings of the 37th WEDC International Conference. Hanoi: Construction Publishing House.

Nunnenkamp, P., Ohler, H., \& Andres, M. S. (2017). Need, merit and politics in multilateral aid allocation: A district-level analysis of World Bank projects in India. Review of Development Economics, 21(1), 126-156.

OECD. (2005). Paris declaration for development aid effectiveness. Paris: OECD.

OECD. (2008). Accra agenda for action. Paris: OECD.

OECD. (2011). Busan partnership for effective development co-operation. Paris: OECD.

OECD. (2012). Harmonisation of donor practices, in aid effectiveness 2011: Progress in implementing the Paris
Declaration. Paris: OECD.

Oh., J., \& , Kim, Y. (2015). Proliferation and fragmentation: Uphill struggle of aid effectiveness. Journal of Development Effectiveness, 7(2), 92-207.

Ohler, H., \& Nunnenkamp, P. (2014). Needs-based targeting or favoritism? The regional allocation of multilateral aid within recipient countries. International Review for Social Sciences, 67(3), 420-446.

Oya, C. (2006). The political economy of development aid as main source of foreign finance for poor African countries: Loss of policy space and possible alternatives from East Asia. Paper presented at International Forum on Comparative Political Economy of Globalisation, Renmin University of China, Beijing.

Quibria, M. G. (2014). Aid effectiveness: Research, policy and unresolved issues. Development Studies Research: An Open Access Journal, 1(1), 75-87.

Reltien, R. (2001). The geopolitics of hunger, 2000-2001: Hunger and power/action against hunger. Boulder, CO: Lynne Rienner Publishers.

Renzio, P., \& Hanlon, J. (2009). Mozambique: Contested sovereignty? The dilemmas of aid dependence. In L. Whitfield (Ed.), The politics of aid: African strategies for dealing with donors (pp. 246-270). Oxford: Oxford University Press.

Resnick, D. (2012). Two steps forward, one step back: The limits of foreign aid on Malawi's democratic consolidation. Helsinki: UNU-WIDER.

Rogerson, A. (2005). Aid harmonization and alignment: Bridging the gaps between reality and the Paris reform agenda. Development Policy Review, 23(5), 531-552.

Sachs, J. (2006). How to help the poor: Piecemeal progress or strategic plans? The Lancet, 367, 1309-1310.

Said, J., McGrath, J., Grant, C., \& Chapman, G. (2011). Evaluating aid-for-trade on the ground: Lessons from Malawi (Issue Paper, No. 21). Geneva: ICTSD.

Tambulasi, R. (2009). All that glistens is not gold: The impact of decentralization on corruption in the local governance system in Malawi. Development Southern Africa, 26(2), 324-340.

van der Meer, E., Tostensen, A., Slob, A., \& Jerve, A. M. (2008). Managing aid exit and transformation Malawi: Country case study. Stockholm: Swedish International Development Agency.

Von Hagen, M., \& Schulz, N. (2009). Silently leaving Malawi: Sweden's delegated exit. Madrid: FRIDE.

Wolfensohn, J. D. (1999). A proposal for a comprehensive development framework (Discussion draft). Washington, DC: World Bank.

Woods, N. (2008). Whose aid? Whose influence? China, emerging donors and the silent revolution in development assistance. International Affairs, 84(6), 1205-1221.

Wroe, D. (2012). Donors, dependency and political crisis in Malawi. African Affairs, 111(442), 135-144.

Yanguas, P. (2014). Leader, protester, enabler, spoiler: 
Aid strategies and donor politics in institutional assistance. Development Policy Review, 32(3), 299-312.
Yanguas, P. (2018). Why we lie about aid: Development and the mess politics of change. London: Zed Books.

\section{About the Authors}

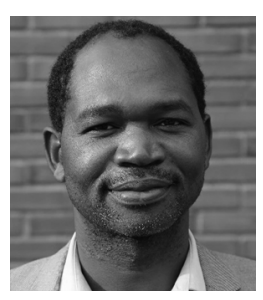

Michael Chasukwa is a Senior Lecturer and Head of the Department of Political and Administrative Studies at the University of Malawi. He has a doctorate in development studies from the University of Leeds. Dr. Chasukwa specializes in development cooperation, political economy, institutions, public policy, decentralization and local government. He has carried out various assignments on governance and development commissioned by the World Bank, Food and Agriculture Organization, Tilitonse Foundation, Oxfam, ActionAid, IrishAid, and DanChurch Aid, among others. His work is published in peer reviewed journals including International Journal of Public Administration, Africa Review, Journal of Development Effectiveness, Journal of Asian and African Studies, Insight on Africa and Malawi Law Journal.

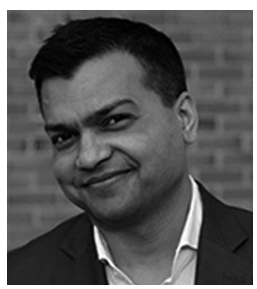

Dan Banik is Professor of political science and Research Director at the Centre for Development and the Environment, University of Oslo, Norway. His research interests include poverty, food security, famine, legal empowerment, aid and the 2030 Agenda for sustainable development. Prof. Banik directs the Oslo SDG Initiative (sum.uio.no/sdg) and writes a weekly column for The Nation (Malawi). He has previously served as the Head of the Norwegian-Finnish Trust Fund in the World Bank for Environmentally and Socially Sustainable Development and on the Board of the Norwegian Crown Prince and Crown Princess's Foundation. His books include Political Transition, Poverty and Inclusive Development in Malawi: The Democratic Dividend (with Blessings Chinsinga, Routledge, 2016), The Legal Empowerment Agenda: Poverty, Labour and the Informal Economy in Africa (2011, Ashgate), Poverty and Elusive Development (2010, Scandinavian University Press) and Starvation and India's Democracy (2009, Routledge). Twitter: @danbanik 